\title{
Compounds and multi-word expressions in Hungarian
}

The notion of compounding is notoriously difficult to define and there are hardly any universally accepted criteria for determining what a compound is. In the present chapter we will make a distinction between prototypical compounds and non-prototypical compounds. The latter but not the former are syntactically separable. All compounds are right-headed and are inflected as a whole. Moreover, according to the received view compounds express a conceptual unit though it is not easy to define what exactly this means. Finally, typically only the first syllable of a compound bears stress.

Compounding is a rather late development in the history of Hungarian. Though compounds can be found sporadically before the $18^{\text {th }}$ century, during the language reform (end of $18^{\text {th }}$ and beginning of $19^{\text {th }}$ century) new compounds were massively created partly by using existing patterns and partly by loans mainly from German. This explains why productive patterns of root (endocentric) compounds are - as far as the categories involved are concerned - identical in Hungarian and German. ${ }^{1}$

The structure of our chapter is as follows: in the first part of the chapter we are going to provide an overview of productive compounding patterns, i.e. root compounds, morphologically marked compounds, deverbal compounds and coordinative compounds. Section 2 is devoted to the description of compound-like phrases in Hungarian, i.e. preverb + verb constructions and bare noun + verb constructions. Finally, Section 3 summarizes the main conclusions of the chapter.

\section{Prototypical compounds}

\subsection{Root compounds}

Let us first have a look at root compounds. A root compound is a compound whose head is not deverbal or whose non-head does not have the function of argument of the verb from which the head is derived. The productive patterns

1 Sections 1.1 through 1.3 and 2.2 are heavily based on our earlier works on the subject. Cf., in particular, Kiefer (1992, 1993, 2009) and Kiefer and Németh (2018).

Ә Open Access. (c) 2019 Kiefer/Németh, published by De Gruyter. (@) Br-Nc-ND This work is licensed under the Creative Commons Attribution-NonCommercial-NoDerivatives 4.0 License. 
involve nouns and adjectives only, there are no productive patterns with adverbs and/or verbs. All endocentric compounds in Hungarian are right-headed and are formed by juxtaposition of the relevant lexical items. No morphological markers appear between the constituents of root compounds. (1a-d) shows the chart of productive patterns. ${ }^{2,3}$
(1a) $\mathrm{N}+\mathrm{N}$
város+háza
'city hall'
tök+mag
'pumpkin seed'
(1b) $\quad \mathrm{A}+\mathrm{N}$
kis+autó
'small car'
meleg+ágy
'hotbed'
(1c) $\mathrm{N}+\mathrm{A}$
kö+kemény
'stone hard'
oszlop+magas
'pillar high'
(1d) $\mathrm{A}+\mathrm{A}$
sötét+zöld
'dark green'
bal+liberális
'left-liberal'

Recently a fifth pattern seems to be gaining ground in addition to the ones shown in (1a-d), namely the pattern $\mathrm{N}+\mathrm{V}$. It can be argued, however, that the corresponding compounds are (at least in the majority of cases) backformations from the corresponding deverbal compounds. For some examples, cf. $(2 \mathrm{a}-\mathrm{c}) .^{4}$

\footnotetext{
2 In Hungarian compounds are usually written as one word. In the examples the constituents are written separately for the sake of clarity.

31 = first person; 3 = third person; ACC = accusative; $\mathrm{COM}=$ comitative; $\operatorname{COND}=$ conditional; $\mathrm{DAT}=$ dative; $\mathrm{DEF}=$ definite; INF = infinitive; INSTR = instrumental; INTR = intransitive; LOC = locative; NMLZ = nominalization; PL = plural; POSS = possessive; PREV = preverb; $\mathrm{PST}=$ past PTCP = parti ciple; $\mathrm{RES}=$ resultative; $\mathrm{SG}=$ singular; $\mathrm{TEMP}=$ temporal (terminative).

4 Cf. also Ladányi (2007: 64 f.).
} 
(2a) $\mathrm{N}+\mathrm{V}$

gép+ír

machine write

'write on a typewriter'

from gép+ír-ás ${ }^{5}$

machine writing

'typing'

(2b) ház+kutat

house search (verb)

from ház+kutat-ás

house search (noun)

(2c) tömeg+közlekedik

mass run

from tömeg+közleked-és

mass/public transportation

Similar examples are legion. It should be noted, however, that compounds such as $(2 \mathrm{a}-\mathrm{c})$ are more frequent in everyday and newspaper language than in literary language.

\subsection{Morphologically marked compounds}

Compounds in Hungarian may be morphologically marked or morphologically unmarked. In the first case the morphological marker may appear either on the first or on the second member of the compound, e.g. újjá+épit (új 'new' + -já 'translative case suffix' + épít 'build') 'reconstruct', tévét néz' (tévé 'television' + $t$ 'accusative case suffix' + néz 'look, watch') 'watch television'. In such cases the head of the compound is always a $\mathrm{V}$ and the nonhead is a syntactic or semantic argument of the verb. Note that neither újjá nor tévét are independent lexical items. Moreover syntactic rules may manipulate the internal structure of such

5 ás/és is a nominalizing suffix, the choice between the two forms is determined by vowel harmony. The usual phonological notation is $-V s$ where $\mathrm{V}$ denotes the harmonizing vowel, i.e. -ás or -és.

6 In contrast to phrases such as könyv-et néz book acc look 'look at a book, on books', kép-et néz 'look at a picture on pictures', which are not compound-like since they don't share any property of compounds. Cf. Section 2.2 for a more detailed discussion of 'bare object noun + verb' constructions. 
compounds, in other words these compounds must be considered non-prototypical.

The morphological marker appears on the second member of the compound if it is derived from a possessive construction, e.g. város +háza (város 'city' + ház 'house' + - $a$ 'possessive suffix') 'city hall', tojás+fehérje (tojás 'egg' + fehér 'white' + -je 'possessive suffix') 'egg-white'. Neither can the members of such compounds be separated by syntactic rules. In this sense they belong to prototypical rather than to non-prototypical compounds. Note that the second member of such compounds is not an independent word: ^háza, *fehérje. Though such compounds are rather frequent, it is unclear to what extent the pattern is productive and/or rule-governed.

Another case where the second member of the compound is morphologically marked are $\mathrm{N}+\mathrm{A}$ compounds in which the head is derived from a past participle. In such compounds the participle is suffixed by the $3 \mathrm{P}$ personal suffix and the nonhead is interpreted as a kind of causer, i.e. of being the cause of the eventuality, normally referred to as Natural Force.

$\begin{array}{ll}\text { (3a) } & \text { vihar+ver-t-e } \\ & \text { storm+beat-PTCP-3sG } \\ \text { 'storm-beaten' } \\ \text { (3b) viz+mos-t- } a \\ \text { water+wash-PTCP-3sG } \\ \text { 'water-lashed' }\end{array}$

Once again the participial head adjective of the compound is not an independent word: *verte, ${ }^{\star}$ mosta ${ }^{8}$ At first sight it would seem that in these compounds the first member satisfies the subject argument of the deverbal head. However, such an analysis would run counter the received view that subject arguments cannot be satisfied in compound structure (cf., for example, Di Sciullo/Williams 1987). The analysis of $\mathrm{N}+\mathrm{A}$ constructions with participial heads as verbal compounds is not mandatory, however. It can be argued that these constructions are participial constructions rather than genuine compounds (cf. Kenesei 1986). Productive participial constructions must be distinguished from frozen ones, while the former can freely be modified, modification is impossible in the latter case. Compounds

7 Though it is often used in certain contexts as a shortened form of tojásfehérje 'egg-white'. 8 Note that verte and mosta are identical with the 3P Sg Past Tense forms of the verbs ver 'beat' and mos 'wash', respectively. 
such as víz+mosta 'water-lashed', por+lepte 'covered with dust' are frozen expressions. In contrast, an expression such as (4),

(4)

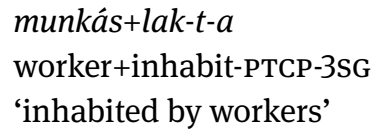

can be modified: it is possible to say sok/kevés munkás lakta 'inhabited by many/ few workers'. Since modification of the nonhead is not possible in the case of genuine compounds we must conclude that the participial constructions such as (4) are not compounds.

\subsection{Deverbal compounds}

Deverbal compounds are special and have received much attention in the pertinent literature because there is a clear argument-head relationship between the elements of the compound. In this case two questions need to be answered: (i) what kind of arguments can the head inherit from its base; (ii) which arguments can be satisfied by the nonhead.

Nouns can be derived from verbs by means of the suffix -âs and in a considerable number of cases the derived nouns can be interpreted as event nouns, e.g. ír-ás 'writing' (from the verb ír 'write'), olvas-ás 'reading' (from the verb olvas 'read'). ${ }^{9}$ If such an event noun occurs as the head of a compound the nonhead can be interpreted as an argument of the verb. Apparently in the case of a deverbal noun derived from a transitive verb the only argument which can occur in nonhead position is the object argument:
(5a) levél+ír-ás
letter+write-NMLZ
'letter writing'
(5b) könyv+olvas-ás
book+read-NMLZ
'book reading'

\footnotetext{
9 In the case of resultative verbs the derived nominal may be ambiguous between the action and result reading. The deverbal noun Italics may mean the activity of writing but also the result of writing.
} 
(5c) levél+ír-ás-a Péternek

letter+write-NMLZ-POS Peter.DAT

'writing a letter to Peter'

(5d) *levél Péternek+írás-a

letter Peter.DAT+write-NMLZ-POS

In (5c) the dative form Péternek can never occur in compounds.

The situation is similar in (6) where Péterrel 'with Peter' is the comitative form of the noun:

(6a) találkoz-ás Péterrel

meet-NMLz Peter.com

'meeting with Peter'

(6b) «Péterrel találkoz-âs

Peter.com meet-NMLZ

The following generalizations hold:

(7a) If the deverbal head of a compound is derived from a transitive verb the only argument which can occur in nonhead position is the object argument.

(7b) No other internal argument can occur in compounds.

The subject argument is normally considered to be an external argument and it is claimed that external (subject) arguments can never occur in nonhead position. In Hungarian the following examples seem to contradict this generalization.

(8a) hó+es-és

snow+fall-NMLZ

'snowfall'

(8b) motor+zúg-ás

engine+buzz-NMLZ

'hum of the engine'

(8c) dió+ér-és

walnut+ripen-NMLZ

'ripening of walnuts'

(9a) liba+gágog-ás

goose+gaggle-NMLZ

'gaggling of a goose' 
(9b) kutya+ugat-ás

dog+bark-NMLZ

'barking of a dog'

(9c) gyermek+sír-ás

child+cry-NMLZ

'crying of a child'

In the theory of thematic roles normally a distinction is being made between an intentionally acting (normally human) agent and an unintentionally acting actor. In both cases the nonhead is not an agent who acts intentionally in order to change the world, the event is rather brought about by natural force or an unintentionally acting actor. This means that the generalization (7b) can be saved if we restrict it to agent arguments, i.e. it can be claimed that agent arguments cannot occur in nonhead position. On the other hand, actor arguments are not excluded from this position. Notice furthermore that the compounds in $(8 a-c)$ and $(9 a-c)$ seem to fall into two semantic classes: $(8 a-c)$ describe phenomena of nature, while $(9 a-c)$ describe events of unintentional sound production.

Next consider the following examples. The verb csökken 'decrease' is intransitive, its transitive counterpart is csökken-t. Prices can decrease transitively and intransitively as shown by (10a-b).

(10a) ár+csökken-és

price+decrease.INTR-NMLZ

'drop in prices'

ár+drágul-ás

price+go.up-NMLZ

'rise of prices'

(10b) ár+csökken-t-és

price+decrease-ACC-NMLZ

'reduction of prices'

ár+drágít-ás

price+raise-NMLZ

'raising of prices'

The examples in $(10 a-b)$ demonstrate the difference between a head derived from an intransitive and a head derived from a transitive verb. In (10a) the nonhead can only be interpreted as the actor argument of the verbal base. In contrast the head in (10b) is derived from a transitive verb, hence the nonhead is interpreted as the object argument of the verbal base. 
There are a number of compounds in which the nonhead looks very much like an actor argument but it can be shown that the relation between nonhead and head can only be interpreted conceptually but not syntactically. Consider:
(11a) bolha+csip-és
flea+sting-NMLZ
'flea-bite'
(11b) kutya+harap-ás
dog+bite-NMLZ
'dog-bite'
(11c) disznó+túr-ás
pig+root-NMLZ
'rooting of pigs'

In the examples in (11) the head noun is a result nominal (referring to the result of biting or rooting) which has not inherited the argument structure of the base verb, hence argument satisfaction does not arise. The properties of result nominals are well-known from the relevant literature which we will not repeat here. Suffice it to mention that result nominals are incompatible with durative temporal adverbials while action nominals are.

Before embarking on the discussion of coordinative compounds it should be made clear that deverbal compounds can also be formed by means of the participial suffixes - $\hat{o}^{10}$ (present participle) and - $t$ (past participle). E.g. dió+darál-ó 'nut grinder' and sertés+sül-t 'roast pork' (from sül 'roast').

\subsection{Coordinative compounds}

Formally, there are two main categories of coordinative compounds in Hungarian: actual coordinatives and compounds derived by lexical reduplication.

As Kiefer (2000: 525) points out, actual coordinative compounds are derived from free lexemes, as shown in (12a) below.

(12a) ad-vesz (from ad 'give' + vesz 'buy') 'mart, buy and sell' jön-megy (from jön 'come'+ megy 'go') 'come and go, fidget' üt-ver (from üt 'hit'+ ver 'beat') 'beat, pound'

10 Denoting the suffixes -ó or -ő where once again the choice is determined by vowel harmony. 
jâr-kel (from jár 'walk' + kel 'traverse') 'go about, shuttle'

él-hal (from él 'live' + hal 'die') 'be overfond of sth'

eszik-iszik (from eszik 'eat' + iszik 'drink') 'eat and drink, regale oneself'

(12b)

$\star /$ ?rohan-szalad (rush + run)

*/?szeret-imád (love + adore)

*/?sir-bög (cry + bellow)

*/?esik-zuhan (fall + dive, tumble)

*/?nyomtat-szkennel (print + scan)

The ill-formed examples in (12b) above are meant to demonstrate the limited productivity of the construction type: the compounds in (12a) are all fully lexicalized, frozen items, while derivation from other non-bound elements seems to be rather problematic.

Another type of coordinative compounds is derived by lexical reduplication, which has several subcategories, as shown in (13).

(13a) alig-alig (hardly + hardly) 'hardly, with great difficulty'

sok-sok (many + many) 'very many'

olykor-olykor (sometimes + sometimes) 'rarely, seldom'

(13b) egyszer-egyszer (once + once) 'sometimes, rarely'

$k i-k i$ (who + who) 'each'

(13c) tarka-barka (from tarka 'colourful, spotty')

'very colourful, spotty'

csiga-biga (from csiga 'snail') '(tiny, sweet) snail'

cica-mica (from cica 'kitten') '(tiny, sweet) kitten'

(13d) dimbes-dombos (from domb 'hill' + -os 'adjectivizing suffix')

'hummocky, full of hills'

girbe-görbe (from görbe 'curved') 'full of curves, sinuous'

rissz-rossz (from rossz 'bad') 'very bad'

(13e) irul-pirul (from pirul 'blush') 'blush, be blushful' izeg-mozog (from mozog 'move') 'fidget, wiggle' ici-pici (from pici ‘tiny') 'very tiny'

The examples in $(13 \mathrm{a}-\mathrm{b})$ demonstrate the case of total lexical reduplication, where the base is copied without modification. Semantically, the derivation serves the purpose of intensification, i.e. the meaning of the compound is analogous with that of the reduplicated base, which means that the derivation only adds the feature of intensification to the base (cf. 13a). However, in some lexicalized cases the meaning of the compound is totally different from that of the base (cf. 13b) (cf. Kiefer 2000: 524 f.; Brdar/Brdar-Szabó 2014). 
Another type of lexical reduplication is when the base is copied with some kind of modification: either an initial consonant of the base is replaced by another one (cf. 13c), or there is a vowel alternation pattern similar to ablaut (cf. 13d). Brdar/Brdar-Szabó (2014: $39 \mathrm{f}$.) label the former phenomenon as inexact total reduplication or rhyming(-motivated) reduplication, and the latter as ablaut-motivated reduplication. Finally, the examples in (13e) are instances of partial reduplication, where only a segment of the base is copied (ibid.: 39).

Note that in these cases, too, the semantic feature added to the base is intensification, and the compounds mainly serve as stylistic versions of their bases: they mostly express the endearing attitude of the speaker, thus they should be dealt with in a morphopragmatic framework as well.

\section{Compound-like phrases}

We have already mentioned some cases of non-prototypical compounds; in the present section a more detailed analysis of such constructions will be provided.

\subsection{Preverb + verb constructions}

In Hungarian preverbs (particles attached to the verb base) are all separable and can fulfil various functions. If fully grammaticalized they express telicity, the most typical being the preverb meg which has completely lost its original meaning and has become an aspectual marker. Among other things, it can express the resultative Aktionsart as in the case of fó $z$ 'cook' - meg+fö $z$ 'cook.RES', varr 'sew' - meg+varr 'sew.Res' or the semelfactive Aktionsart as in vakar 'scrape' - meg+ vakar 'scrape once', csóvál 'wag' - meg+csóvál 'wag once'.

Most preverbs are less grammaticalized yet they can be used to derive an Aktionsart. For example, the preverb el (whose original directional meaning is 'away') can be used to express inchoativity if it is accompanied by the reflexive pronoun magát 'self', e.g. ordít 'shout, cry' - el+ordítja magát 'cry out' or nevet 'laugh' - el+neveti magát 'burst out laughing'. In addition to meg some other originally directional preverbs can be used to express resultativity: takarít 'tidy, clean' - ki+takarít 'clean up', gereblyéz 'rake' - fel+gereblyéz 'rake up', kaszál 'scythe' - le+kaszál 'scythe.RES', költ 'spend' - el+költ 'spend.REs'.

At first sight Aktionsart-formation may seem to belong to derivational morphology. This would, however, contradict several generalizations concerning derivational morphology in Hungarian. First, derivational affixes harmonize with 
the verbal stem (szép-ség 'beauty', jó-ság 'goodness'), in contrast, preverbs never harmonize. ${ }^{11}$ Second, derivational affixes may change the part of speech category of the base which is not the case with preverbs. Third, derivational affixes are bound morphemes. On the other hand, preverbs can be detached from their base. First, they can be used in short answers to a question without their base as in (14-15) below.

(14a) Meg+írtad a levelet?

'Have you written the letter?'

(14b) Meg.

'Yes.'

(15a) Ki+mentél a kertbe?

'Have you gone out into the garden?'

(15b) Ki.

'Yes.'

Moreover, preverbs can freely be moved to various positions in the sentence, $\mathrm{cf}$. the variants of $(15 a)$ in $(16 a-c)$.

(16a) A kertbe mentél ki?

(16b) Ki a kertbe mentél?

(16c) Mentél ki a kertbe?

We may thus conclude that the formation of complex verbs cannot be part of derivational morphology. On the other hand, preverb+verb constructions are not prototypical compounds either, at least not with respect to their behavior vis-avis syntax. In other words, their internal structure is accessible to syntactic rules. Yet they are compounds semantically as testified, among other things, by the large number of lexicalized forms. It should also be noted that a large number of preverbs are undistinguishable from the formally identical adverbs.

An interesting property of the Hungarian preverbs is that they can be reduplicated to express iterativity. ${ }^{12}$ Consider:

11 Preverbs with a front vowel such as $k i$ can easily be attached to back vowel stems as in $k i+m a r$ 'corrode', ki+old 'undo', ki+rúg 'kick out'.

12 Iterativity can also be expressed by the verbal suffix -gat which is, however, semantically radically different from the iterativity expressed by preverb reduplication. 
(17a) Ki-ki+megy a kertbe. PREV-PREV+go the garden.LOC

'From time to time he/she goes out into the garden.'

(17b) Meg-meg+ír egy levelet.

PREV-PREV+write the letter.ACC

'From time to time he/she writes a letter.'

The type of iterativity is one of the Aktionarten in Hungarian which, however, is not expressed by a particular preverb or suffix but by reduplicating the preverb. Note that reduplicated preverbs cannot be separated from the verb base by another constituent and they cannot be moved after the verbal base either. From this property it follows that reduplicated verbs cannot be negated since the negative particle nem must immediately precede the verbal base, cf. (18). External negation is, of course, possible (19).

\begin{tabular}{|c|c|c|c|c|c|c|c|}
\hline (18a) & $\begin{array}{l}{ }^{\star} \mathrm{Nem} \\
\text { not }\end{array}$ & & $\begin{array}{l}\text { meg- } n \\
\text { PREV- }\end{array}$ & $\begin{array}{l}g+i r \\
E V+V\end{array}$ & & $\begin{array}{l}\text { egy } \\
\mathrm{a}\end{array}$ & $\begin{array}{l}\text { levelet. } \\
\text { letter.Acc }\end{array}$ \\
\hline$(18 b)$ & $\begin{array}{l}{ }^{\star} \mathrm{Nem} \\
\text { not }\end{array}$ & & $\begin{array}{l}\text { ir } \\
\text { write }\end{array}$ & $\begin{array}{l}\text { egy } \\
\mathrm{a}\end{array}$ & $\begin{array}{l}\text { levelet } \\
\text { letter.AcC }\end{array}$ & & $\begin{array}{l}\text { meg-meg. } \\
\text { PREV-PREV }\end{array}$ \\
\hline (19) & $\begin{array}{l}\text { Nem } \\
\text { not }\end{array}$ & $\begin{array}{l}\text { igaz, } \\
\text { true }\end{array}$ & $\begin{array}{l}\text { hogy } \\
\text { that }\end{array}$ & $\begin{array}{l}\text { meg } \\
\text { PRE }\end{array}$ & $\begin{array}{l}g g+i ́ r \\
\text { REV+write }\end{array}$ & $\begin{array}{l}\text { egy } \\
\mathrm{a}\end{array}$ & $\begin{array}{l}\text { levelet. } \\
\text { letter.ACc }\end{array}$ \\
\hline
\end{tabular}

These properties seem to suggest that reduplicated forms are not only semantically but also syntactically words. First they have a specific meaning (to do something repeatedly), second syntactic rules cannot change their internal structure.

Preverb reduplication is not possible across the board: it must obey a phonological and several semantic constraints. The phonological constraint refers to the length of the preverb in terms of the number of syllables: preverbs longer than two syllables cannot be reduplicated, as shown by (20).

(20a) *utána-utána+megy 'go after, follow' (lit. after-after go)

(20b) *keresztül-keresztül+vág ‘cut through' (lit. through-through cut)

As far as the semantic constraints are considered, apparently activities if pushed to the extreme cannot be reduplicated. The preverbs túl 'over', agyon 'over', tönkre 'over' are used to express the extreme degree of an activity, therefore it does not come as a surprise that such preverbs cannot be reduplicated. Consider: 
(21a) `túl-túl+hangsúlyoz 'over stress' (lit. over-over stress)

(21b) ^agyon-agyon+hajszol 'over-fatigue, work to death' (lit. over-over work)

(21c) `tönkre-tönkre+dolgozza magát 'work oneself to death' (lit. over-over work)

\subsection{Bare noun + verb constructions}

According to the literature (Kiefer 1990; Farkas/de Swart 2003), Hungarian bare noun + verb constructions (in short, BNV constructions) are instances of type I noun incorporation in terms of Mithun (1984). Mithun describes the phenomenon as a type of compounding where a verb and a noun with the semantic function of patient, location or instrument combine to form a new complex verb. The eventuality designated by the BNV construction is not just a random co-occurrence of an entity and an eventuality, but it is perceived as a recognizable, unitary concept worth labelling (cf. Mithun 1984: $848 \mathrm{f}$.).

We consider the Hungarian BNV construction type as a special case of compounding by juxtaposition, the general characteristics of which are briefly captured by Mithun as follows:

A number of languages contain a construction in which a $\mathrm{V}$ and its direct object are simply juxtaposed to form an especially tight bond. The $\mathrm{V}$ and $\mathrm{N}$ remain separate words phonologically; but as in all compounding, the $\mathrm{N}$ loses its syntactic status as an argument of the sentence, and the VN unit functions as an intransitive predicate. The semantic effect is the same as in other compounding: the phrase denotes a unitary activity, in which the components lose their individual salience. (ibid.: 849)

The examples in (22)-(23) below demonstrate some of the commonly recognized features of the Hungarian BNV construction type.

\begin{tabular}{|c|c|c|c|}
\hline (22a) & Péter & újságot & olvas. \\
\hline & Peter & newspaper.ACC & read \\
\hline & Péter & zenét & hallgat. \\
\hline & Peter & music.ACC & listen \\
\hline & Péter & tanulmányt & ir. \\
\hline & Peter & article.ACc & write \\
\hline & Péter & keresztrejtvényt & fejt. \\
\hline & Peter & crossword.ACC & solve \\
\hline & Péter & ruhát & próbál. \\
\hline & Peter & outfit.ACC & try on \\
\hline
\end{tabular}

'Peter is reading (a) newspaper(s) / listening to music / writing an article / solving (a) crossword puzzle(s) / trying on (an) outfit(s).' 


\begin{tabular}{|c|c|c|c|c|}
\hline \multirow[t]{10}{*}{ (22b) } & Péter & olvassa & $a z$ & újságot. \\
\hline & Peter & read.3SG.DEF & the & newspaper.ACC \\
\hline & Péter & hallgatja & $a$ & zenét. \\
\hline & Peter & listen.3SG.DEF & the & music.ACC \\
\hline & Péter & írja & $a$ & tanulmányt. \\
\hline & Peter & write.3SG.DEF & the & article.ACC \\
\hline & ?Péter & fejti & $a$ & keresztrejtvényt. \\
\hline & Peter & solve.3SG.DEF & the & crossword.ACC \\
\hline & ?Péter & próbálja & $a$ & ruhát. \\
\hline & Peter & try on.3SG.DEF & the & outfit.ACC \\
\hline
\end{tabular}

'Peter is reading the newspaper / listening to the music / writing the article / solving the crossword puzzle / trying on the outfit.'

$\begin{array}{llllll}\text { */?Péter } & \text { újságot } & \text { olvas, } & \text { és } & \text { elégedett } & \text { vele. } \\ \text { Peter } & \text { newspaper.ACC } & \text { read } & \text { and } & \text { content } & \text { INSTR } \\ \text { */?Péter } & \text { zenét } & \text { hallgat, } & \text { és } & \text { elégedett } & \text { vele. } \\ \text { Peter } & \text { music.ACC } & \text { listen } & \text { and } & \text { content } & \text { INSTR } \\ \text { */?Péter } & \text { tanulmányt } & \text { ir, } & \text { és } & \text { elégedett } & \text { vele. } \\ \text { Peter } & \text { article.ACC } & \text { write } & \text { and } & \text { content } & \text { INSTR } \\ \text { */?Péter } & \text { keresztrejtvényt } & \text { fejt, } & \text { és } & \text { elégedett } & \text { vele. } \\ \text { Peter } & \text { crossword.ACC } & \text { solve } & \text { and } & \text { content } & \text { INSTR } \\ \text { */?Péter } & \text { ruhát } & \text { próbál, } & \text { és } & \text { elégedett } & \text { vele. } \\ \text { Peter } & \text { outfit.ACC } & \text { try on } & \text { and } & \text { content } & \text { INSTR }\end{array}$

'Peter is reading (a) newspaper(s) / listening to music / writing an article / solving (a) crossword puzzle(s) / trying on (an) outfit(s), and he is content with it.'

As pointed out by Kiefer (1990: 153 f.) and shown in (22) above, Hungarian BNVs form one single phonological unit from the point of view of stress assignment (i.e., only the subject and the incorporated object bear stress on their first syllable, cf. 22a), while their V + DP counterparts show the opposite pattern (i.e., the subject, the verb and the direct object all bear separate stress on their first syllable, cf. 22b). The ill-formedness of some of the constructions in (23) is due to the fact that some of these BNVs, namely keresztrejtvenyt fejt 'solve crossword puzzles' and ruhát próbál 'try on outfits' seem to be lexicalized units without exact syntactic paraphrases, e.g. V + DP counterparts.

One of the key semantic features of direct object incorporation, often mentioned in the literature (cf. Mithun 1984; Kiefer 1990; Farkas/de Swart 2003), is the non-referentiality of the bare object noun, which means that the nouns in these BNV constructions do not denote any specific, identifiable entity in the 
world. This feature can be tested by adding an anaphoric pronominal constituent to the sentence, as in (23) above. The examples in (23) are ill-formed because the nouns in each construction have a type referring function, i.e. they only add a specific classificatory feature/component to the eventuality expressed by the verb.

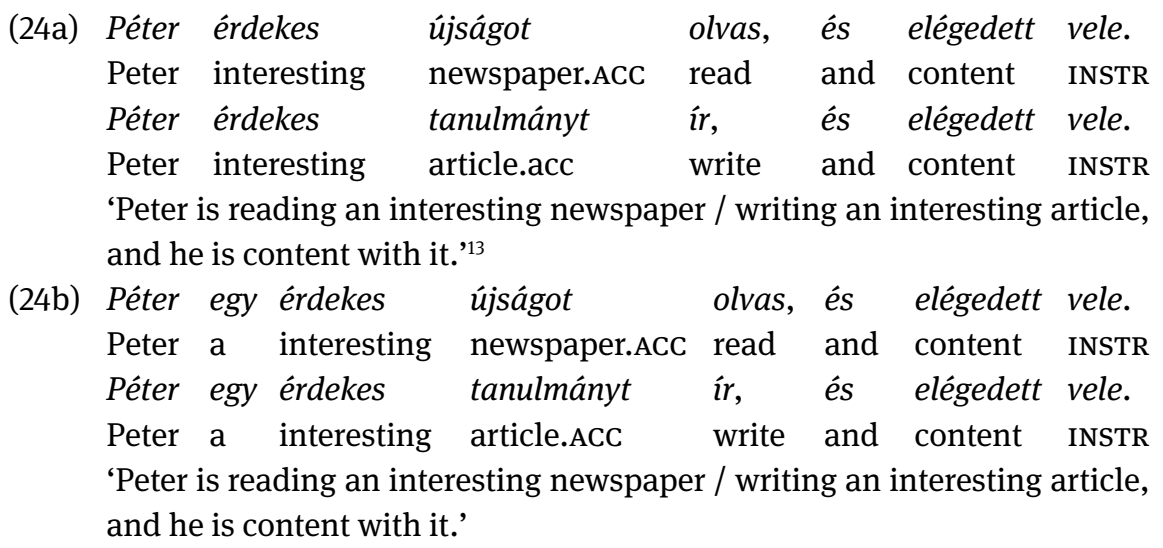

The constructions in (24a) above are meant to demonstrate the effects of modification on BNV constructions. The inserted adjective overrides the non-referentiality property of the object noun and - as a consequence - the complex eventuality meaning of the BNVs. This means that we are dealing with at least two different construction types from the point of view of semantics and discourse transparency, as shown by the fact that, contrary to the case of (23), the modified version of the construction admits the insertion of an anaphoric pronominal constituent into the sentence. As noted in Kiefer (1990: 152), the constructions like those in (24a) seem to be some kind of stylistic variants of the full-fledged construction types shown in (24b).

The number neutrality of the singular incorporated noun is another important characteristic of BNVs, and it is strongly connected to the above mentioned non-referentiality feature. As Farkas/de Swart (2003: 13f.) point out, morphologically singular incorporated nouns are compatible with both atomic and nonatomic interpretations. Most of the examples in (22a) above are underspecified regarding the number of objects involved in the eventualities described by the BNVs. The singular noun in the BNV újságot olvas 'read (a) newspaper(s)', for

13 Similar things were discussed in considerable detail in Maleczki (1994). 
instance, allows for both an atomic (singular) and a non-atomic (plural) interpretation, i.e. the BNV does not specify whether Peter is reading one newspaper or several newspapers one after the other. As shown by the examples in (25) below, the varying interpretations are influenced by pragmatic (contextual) information. The BNV in (25a) triggers an atomic interpretation due to extra linguistic knowledge about marriage related customs (though it would allow for a non-atomic interpretation in the context of legal bigamy), the one in (25b) clearly triggers an atomic interpretation (without any cultural variation), finally, the one in (25c) unambiguously triggers a non-atomic interpretation.

(25a) Feri feleséget keres.
Feri wife.ACc search
'Feri is looking for a wife.'
(25b) Anna napfelkeltét néz az erkélyen.
Anna sunrise.Acc watch the balcony.Loc
'Anna is watching the sunrise on the balcony.'
(25c) Mari bélyeget gyüjt.
Mari stamp.Acc collect
'Mari is collecting stamps.'

As far as plural bare objects are concerned, the following generalization holds: plural bare object nouns form grammatical BNVs, however, as shown in (26) below, their discourse transparency properties are similar to the ones of modified singular objects, as shown in (25a) above.

(26a) Anna leveleket ir, és elküldi óket. Anna letter.PL.ACC write and PREv.send.3SG.DEF them 'Anna writes letters and sends them.'

(26b) Az orvos betegeket vizsgál, és megpróbál segíteni rajtuk. The doctor patient.PL.ACC examine and PREV.try help.INF LOC.3PL 'The doctor examines patients and tries to help them.'

Finally, a distinction must be made between fully productive and idiomatic cases. As pointed out in Kiefer (1990), the meaning of idiomatic BNVs cannot be derived from a corresponding free construction (cf. the examples in (27)-(28) below), while fully productive BNVs generally have matching syntactic paraphrases as already demonstrated by the examples in (23a-b) above. 

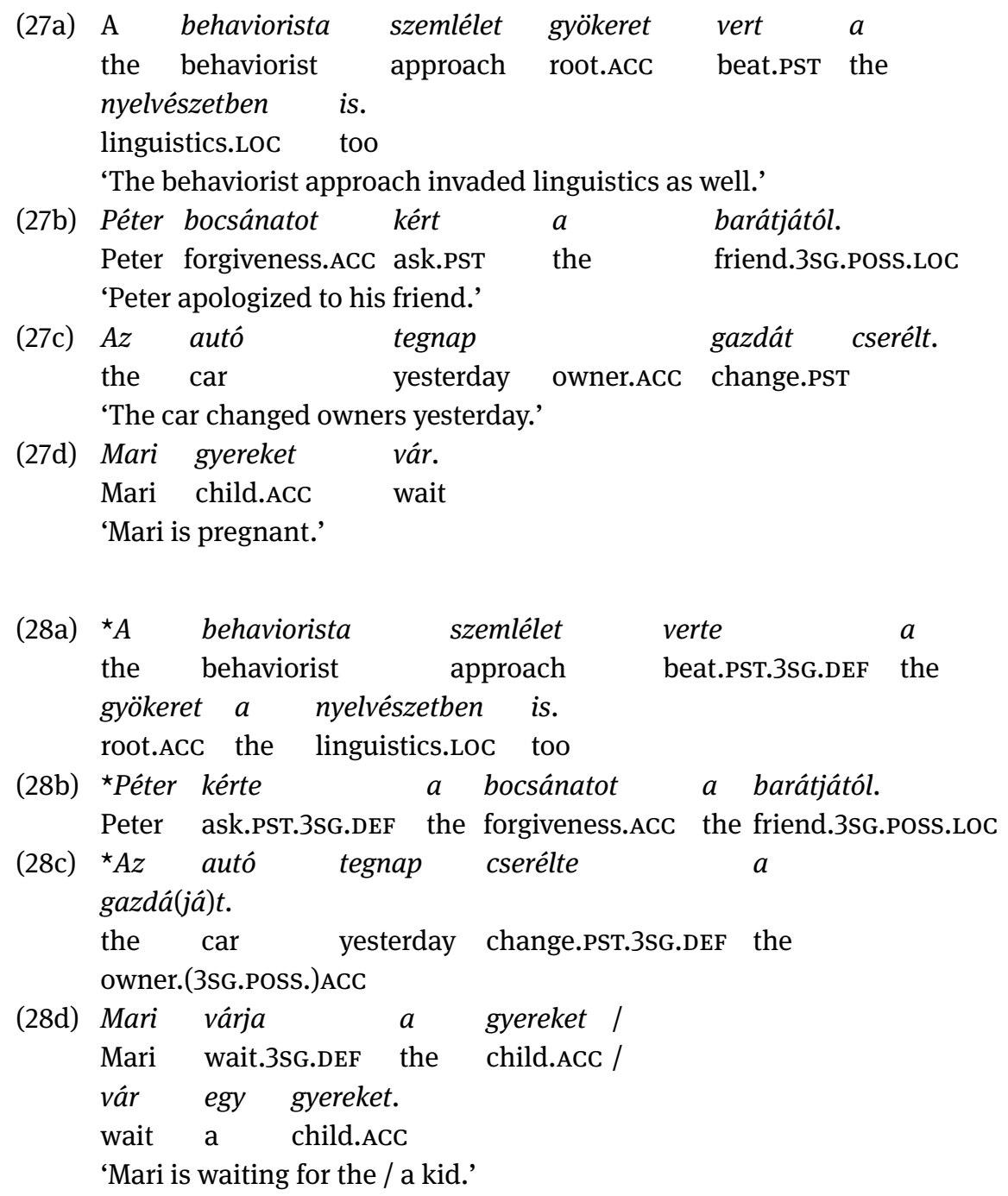

The difference between the lexicalized BNVs in $(27 a-c)$ and $(27 d)$ is that the former type cannot be grammatically matched with a syntactic paraphrase (cf. $(28 \mathrm{a}-\mathrm{c})$ ), while the latter construction type has a well-formed syntactic paraphrase, however, (synchronically) this paraphrase has nothing to do with the meaning of its BNV counterpart (compare (27d) and (28d)). 
As mentioned above, the most prominent and universal semantic and pragmatic feature of BNVs is that the eventuality designated by the construction has to be perceived as a recognizable, unitary concept worth separately labelling. This 'institutionalized' character of the complex activity expressed by the BNV seems to be a strong criterion regarding the derivation of the construction type. Thus it does not come as a surprise that not all bare objects are admitted in BNV constructions with equal ease. Consider the examples in (29b) and (29d) which, as opposed to those in (29a) and (29c), are odd on their generic reading.

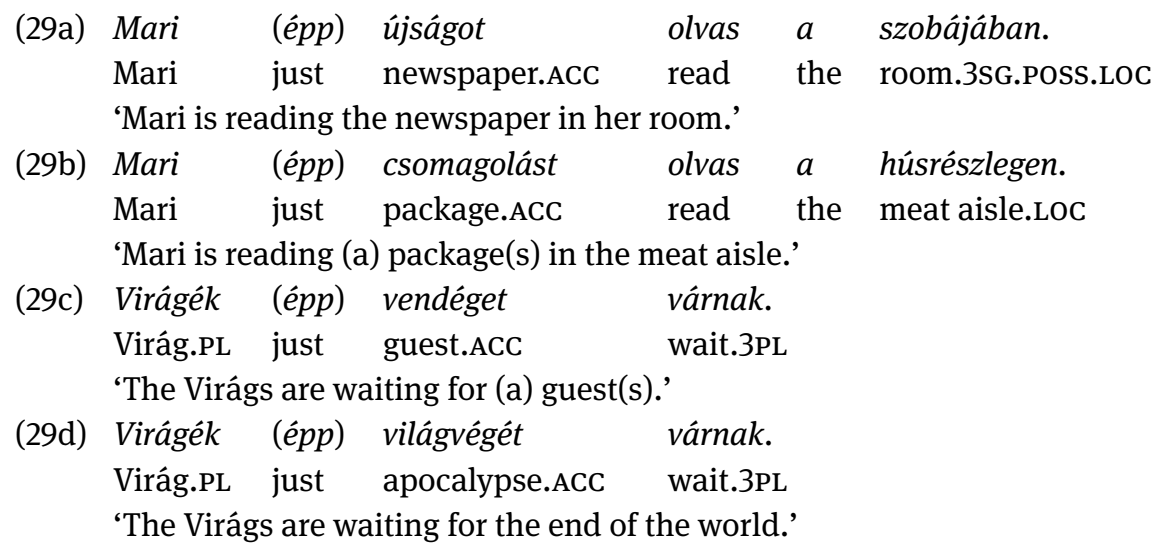

The oddness of (29b) is caused by the fact that, generally speaking, reading packages is not considered a recognizable, re-occurring complex eventuality, however, the BNV in question becomes acceptable if matched with a proper context: if, for example, the participants of the speech situation know that Mari has a habit of reading the package of meat products trying to avoid certain ingredients. The same holds true for (29d) as well: waiting for the end of the world is generally not perceived as an 'institutionalized' activity, nevertheless, the use of the BNV is justified in the context of knowing that the Virágs have prepared for the end of the world on several occasions in the past due to false predictions.

These types of marginal examples show that, although there may be some pragmatic factors that influence the derivation of BNVs, if the contextual factors match the corresponding pragmatic criteria, even seemingly odd BNVs will be considered well-formed.

Finally, mention must be made of the aspectual restrictions filtering the range of input verbs. The generalization seems to be as follows: activity/process verbs, i.e. [+dynamic, -telic] verbs potentiate well-formed BNVs, while accomplishment and achievement verbs, i.e. [+dynamic, +telic] verbs as well as stative, 
i.e. [-dynamic, -telic] verbs do not tend to form grammatical constructions (cf. Kiefer 1990), as shown by the examples in (30) below. ${ }^{14}$

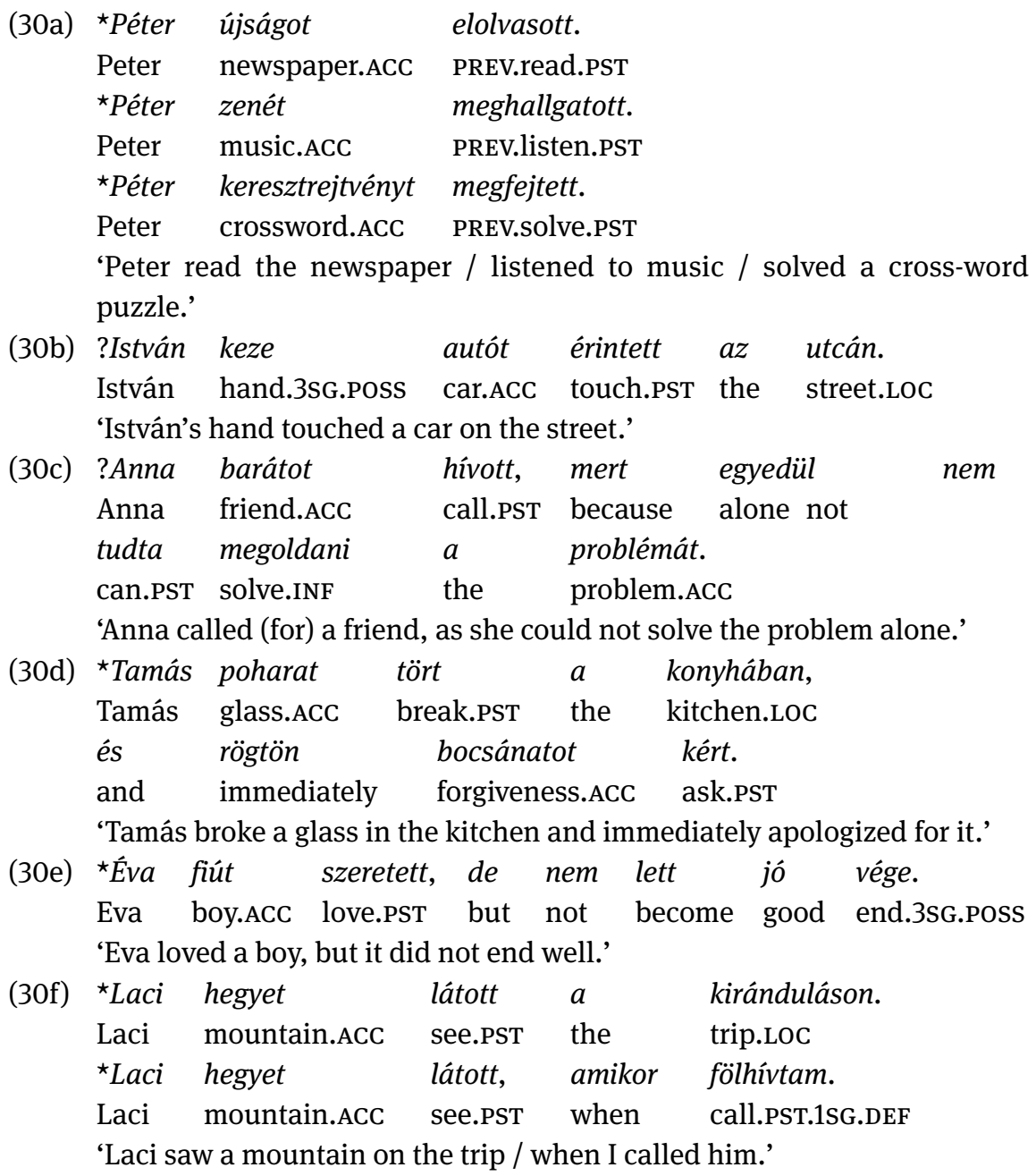

14 We use the terms activity, achievement, accomplishment and state according to the Vendlerian tradition well known in the literature on aspect. Vendler (1967) isolated four situation types: states (e.g. love, know, etc.), activities (e.g. run), achievements (e.g. reach the summit) and accomplishments (e.g. draw a circle). For more on these aspectual categories, cf. Smith (1991), Tenny (1994), Kiefer (2006), etc. 


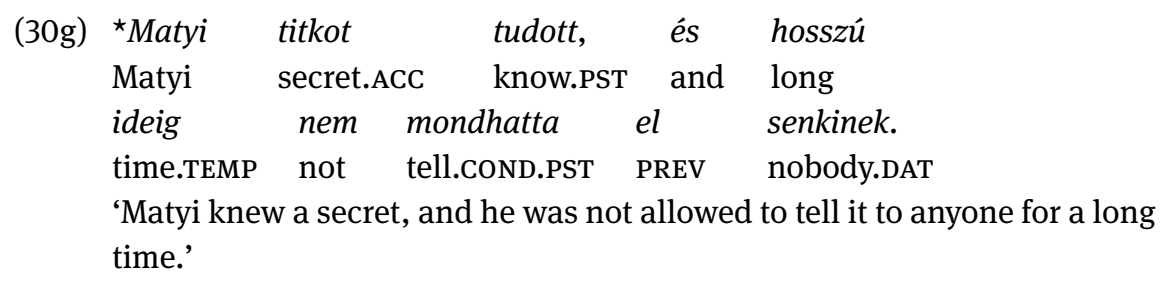

According to these examples, the above generalization seems to hold true for Hungarian BNVs. The constructions in $(30 \mathrm{a}-\mathrm{d})$ derived from telic verbs are ungrammatical, although a distinction should be made between prefixed and unprefixed telic verbs, as the latter are invariably ungrammatical in these constructions, while in some cases the former may serve as acceptable input verbs (as shown in (31a-b) below). ${ }^{15}$ The ungrammatical BNVs like those in (30e-g) lead to the conclusion that stative verbs are indeed excluded from the range of possible input verbs, however, as shown in (31d-e), we may find some grammatical BNVs derived from stative verbs as well.

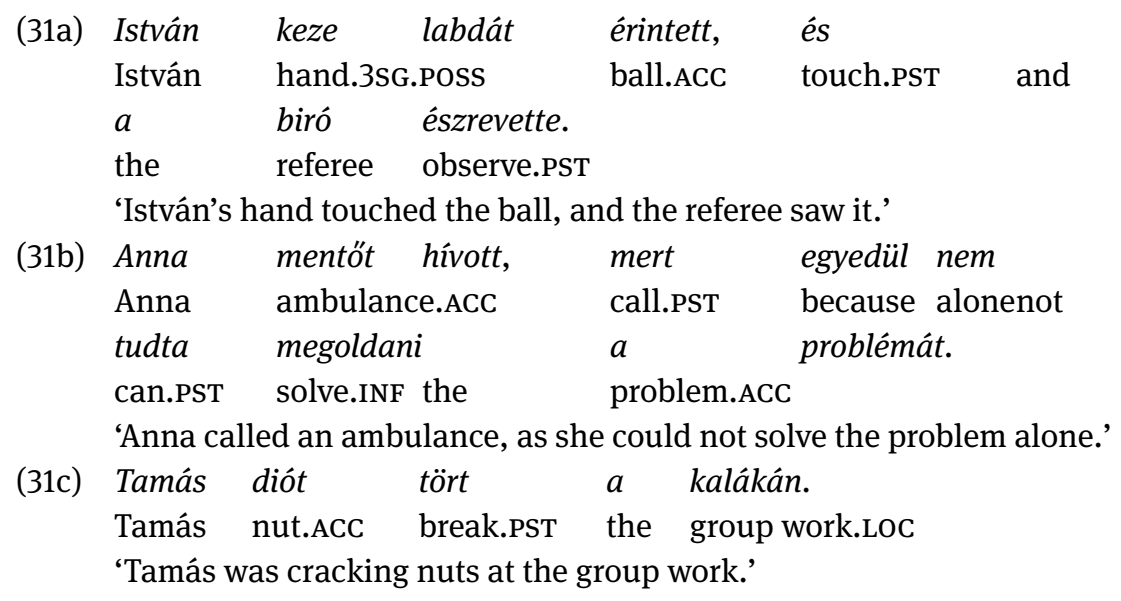

15 The distributional properties of these verb classes are captured in Kiefer (1990: 169) as follows: "Syntactically, both the bare noun and the prefix belong to the same class of elements, often referred to as preverb since under normal circumstances an element of this class occupies the position immediately preceding the verb. Consequently, two preverbs can never co-occur.” 


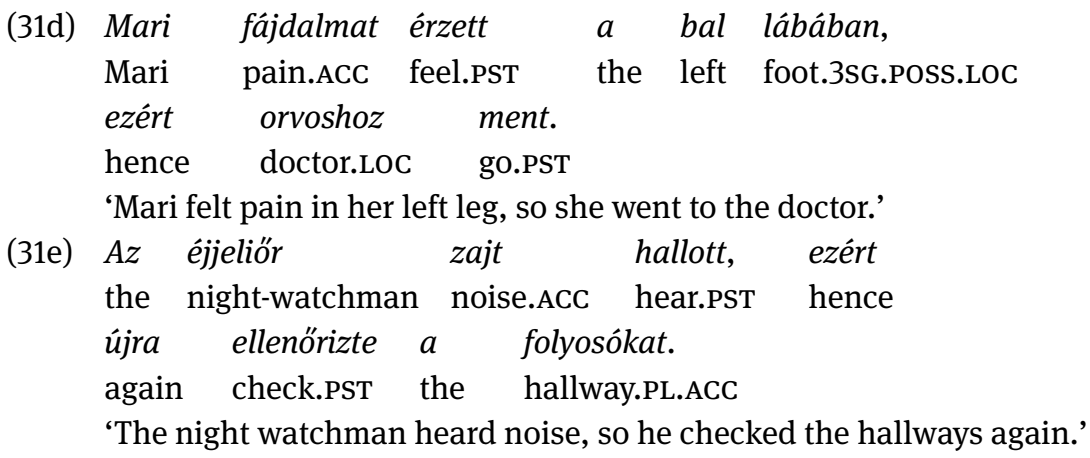

The well-formed examples in (31) violate the aspectual criteria formulated above, so we need to take a closer look at the semantic and pragmatic features of these BNVs. The sentences in (31a-b) contain BNVs derived from telic verbs, while the ones in (31d-e) contain stative verbs. The example in (31c), contrasted with (30d), is meant to demonstrate how contextual non-atomicity entailments induce aspectual coercion in the case of punctual verbs (the BNV triggers an iterative interpretation, otherwise, with an atomic interpretation, it would be considered illformed, like the one in (30d) above; and reversely: the BNV poharat tör 'break glasses' becomes well-formed with an iterative and habitual interpretation).

The common feature of these BNVs is that they all denote institutionalized, re-occurring eventualities. The institutionalized nature of the eventualities expressed by (31a-b) is also shown by their contrast with the constructions in $(30 b-c)$ above: in football, touching the ball with one's hand is a frequent, punishable occurrence. The same institutionalized character holds true for the eventuality of calling an ambulance and for the stative predicates in (31d-e).

Based on these observations, we conclude that the aspectual criterion described above should be reduced to a remark regarding the prevalency of process verbs in BNVs, as the range of verbs which (potentially) denote institutionalized eventualities strongly overlaps with the category of process verbs, however, some telic and stative verbs also describe eventualities which satisfy the pragmatic criterion controlling BNV formation.

\section{Summary}

In the present paper we have summarized the most important facts concerning compounds and compound-like phrases (= non-prototypical compounds) in Hungarian. We have concentrated on the productive, or at least regular patterns of compounding and derivation of compound-like constructions. In particular, 
we have stressed the features which deviate from "Standard Average European". Some of such features can be found in the case of deverbal compounds as well, e.g. that the subject argument can be satisfied in compounds which does not seem to be the case in Germanic or Romance. However, the most striking feature of Hungarian compounding is the existence of bare noun constructions and their relation to verbal aspect.

\section{References}

Brdar, Mario/Brdar-Szabó, Rita (2014): Syntactic reduplicative constructions in Hungarian (and elsewhere): Categorization, topicalization and concessivity rolled into one. In: Rundblad, Gabriella et al. (eds.): Selected Papers from the 4th UK Cognitive Linguistics Conference. London: UK Cognitive Linguistics Association. 36-51.

Di Sciullo, Anna Maria/Williams, Edwin (1987): On the definition of word. Cambridge, MA: The MIT Press.

Farkas, Donka/de Swart, Henriëtte (2003): The semantics of incorporation: From argument structure to discourse transparency. Stanford, CA: CSLI Publications.

Kenesei, István (1986): On the role of the agreement morpheme in Hungarian. ALH 86, 1-4. 104-120.

Kiefer, Ferenc (1990): Noun incorporation in Hungarian. In: Acta Linguistica Hungarica 40, 1-2. 149-177.

Kiefer, Ferenc (1992): Compounding in Hungarian. Rivista di Linguistica 4, 1. 45-55.

Kiefer, Ferenc (1993): Thematic roles and compounds. Folia Linguistica 27, 1-2. 25-55.

Kiefer, Ferenc (2000): A szóösszetétel [Compounds]. In: Kiefer, Ferenc (ed.): Strukturális magyar nyelvtan 3. Morfológia. Budapest: Akadémiai Kiadó. 519-568.

Kiefer, Ferenc (2006): Aspektus és akcióminőség - különös tekintettel a magyar nyelvre [Aspect and Aktionsart - with special emphasis on Hungarian]. Budapest: Akadémiai Kiadó.

Kiefer, Ferenc (2009): Compounding in Hungarian. In: Lieber, Rochelle/Stekauer, Pavol (eds.): Oxford handbook of compounding. Oxford: Oxford Handbooks. 527-541.

Kiefer, Ferenc/Németh, Boglárka (2018): Aspectual constraints on noun incorporation in Hungarian. In: Zoltán, Huba Bartos/den Dikken, Marcel/Váradi, Tamás (eds.): Boundaries crossed: Studies of the crossroads of morphosyntax, phonology, pragmatics, and semantics. Berlin: Springer. 21-32.

Ladányi, Mária (2007): Produktivitás és analógia a szóképzésben [Productivity and analogy in word formation]. Budapest: Tinta Könyvkiadó.

Maleczki, Márta (1994): Bare common nouns and their relation to the temporal constitution of events in Hungarian. In: Dekker, Paul/Stokhof, Martin (eds.): Proceedings of the Eighth Amsterdam Colloquium. Amsterdam: Institute for Logic, Language and Computation, University of Amsterdam. 347-365.

Mithun, Marianne (1984): The evolution of noun incorporation. Language 60. 847-895.

Smith, Carlota (1991): The parameter of aspect. Dordrecht: Springer.

Tenny, Carol L. (1994): Aspectual roles and the syntax-semantics interface. Dordrecht: Springer.

Vendler, Zeno (1967): Verbs and times. Linguistics in philosophy. Ithaca/New York: Duke University Press. 97-121. 